\title{
Hubungan Tipe Kepribadian Berdasarkan Big Five Theory Personality dengan Kebimbangan Karier pada Siswa SMA
}

\author{
Relationship between Types of Personality Based on Big Five \\ Theory Personality with Career Indecision among High School \\ Students
}

\author{
Salma Aulia Utami, Novika Grasiaswaty, Sari Zakiah Akmal \\ Fakultas Psikologi Universitas YARSI, Jakarta \\ email: sari.zakiah@yarsi.ac.id
}

KATA KUNCI : Tipe Kepribadian Big Five, Big Five Inventory, Kebimbangan karier, Career Decision Scale (CDS), Siswa SMA

KEYWORDS : Big Five Theory Personality, Big Five Inventory (BFI), Career indecision, Career Decision Scale (CDS), High School Students

\begin{abstract}
ABSTRAK : Pemilihan jurusan bukan hal yang dapat dilakukan siswa SMA kelas XII dengan mudah. Salah satu kesulitan yang dialami oleh siswa adalah kebimbangan dalam memilih jurusan atau program studi di perguruan tinggi. Kebimbangan karier adalah ketidakmampuan individu untuk memilih program studi tertentu. Penelitian sebelumnya mengungkapkan bahwa faktor kepribadian berperan dalam kebimbangan karier, namun belum menunjukkan hasil yang konsisten mengenai dimensi mana saja yang berperan positif maupun negatif terhadap kebimbangan karier. Penelitian ini dilakukan untuk mengetahui hubungan tipe kepribadian berdasarkan big five theory personality dengan kebimbangan karier pada siswa-siswi SMA kelas XII di Jabodetabek. Sampel yang terlibat sebanyak 128 siswa SMA yang diperoleh menggunakan teknik incidental sampling. Pengambilan data penelitian menggunakan alat ukur Career Decision Scale (CDS) dan Big Five Inventory (BFI). Data diolah dengan menggunakan teknik analisa korelasi. Hasil penelitian menunjukkan bahwa terdapat hubungan positif antara neuroticsm $(r=0,175, \mathrm{p}<0.05)$ dan hubungan negatif antara conscientiousness $(\mathrm{r}=-0,181, \mathrm{p}<0.05)$ dengan kebimbangan karier. Sementara dimensi lainnya seperti: openness to experience, extraversion, agreeableness tidak memiliki hubungan signifikan dengan kebimbangan karier. Oleh karena itu, faktor kepribadian dapat menjadi salah satu aspek yang perlu diintervensi dalam membantu siswa yang mengalami kebimbangan karier.
\end{abstract}

ABSTRACT: Making decision related to choosing a major in university is a complecated process for senior high school students (grade XII), particularly for those with career indecision problem. Career indecision is persons inability to choose a particular course of study. Some studies showed that personality is one of significant factor that correlate with career indecision. However, there are some incosistency related to the particular aspec of personality which is associated with career indecision. This research was conducted to find out the relationship of personality type based on big five theory personality with career indecision among high school students of class XII in Jadebotabek. The sample involved 128 high school students which obtained by using incidental sampling technique. The data were collected by using Career Decision Scale 
(CDS) and Big Five Inventory (BFI) measurements. The results showed that there was a positive relationship between neurotics $(r=0.175)$ with career indecision and negative relationship between conscientiousness $(r=-0.181)$ with career indecision variable. While other dimensions such as: openness to experience, extraversion, and agreeableness has no significant relationship with career indecision. Thus, an intervention to help students with career indecision problem need to consider aspec of personality.

\section{PENDAHULUAN}

Setiap individu akan selalu dihadapkan pada tugas-tugas perkembangan selama hidupnya, tak terkecuali remaja dan dewasa muda (Erikson dalam Papalia, Olds, dan Feldman, 2009). Salah satu tugas perkembangan remaja akhir dan dewasa muda adalah pemilihan karier (Bardick, Bernes, Magnusson \& Witko, 2006; Creed, Patton, \& Prideaux, 2006). Pemilihan karier ini menjadi penting karena konsekuensi akan keputusan ini terus mempengaruhi kehidupan individu tersebut (Jamali, Araqi, \& Kalantarkousheh, 2015). Keputusan dalam memilih karier telah dimulai sejak seseorang menginjak bangku SMA (Pramudi, 2015). Sayangnya, siswa SMA terutama mereka yang duduk di kelas XII masih mengalamai kebimbangan dalam memutuskan kariernya ke depan meskipun telah mendapatkan bimbingan dari orang tua dan pihak sekolah (Guay, 2006).

Kebimbangan karier (career indecision) adalah kesulitan individu dalam membuat keputusan karier dan akademik (Gati \& Saka, 2001). Menurut Osipow dalam Daniels, Stewart, Stupnisky, Perry, dan LoVerso (2011) kebimbangan karier merupakan suatu tahap perkembangan normal yang terjadi oleh setiap individu terutama ketika berada pada masa peralihan atau proses memilih karier. Meskipun demikian, kesulitan tersebut perlu segera diatasi karena dapat menimbulkan dampak negatif jangka panjang seperti kesalahan dalam pemilihan jurusan, prestasi yang tidak optimal di bidang pendidikan dan pekerjaan yang ditekuni. Oleh karena itu, masalah kebimbangan karier pada remaja perlu diatasi.
Terdapat dua faktor yang dapat mempengaruhi seseorang dalam pengambilan keputusan karier yaitu faktor eksternal dan internal. Menurut Gunawan (2001) faktor eksternal meliputi orangtua, sahabat, guru atau pembimbing (Setyowati \& Nursalim, 2009). Sementara itu, faktor internal mencakup nilai-nilai kehidupan, intelegensi, bakat, minat dan kepribadian seseorang (Wandansari, 2004, Fabio, Palazzeschi, \& Baron, 2012). Diantara beberapa faktor yang mempengaruhi proses pengambilan keputusan karier tersebut, faktor kepribadian memiliki peranan yang cukup penting. Hasil penelitian yang dilakukan oleh Sasongko (2015) menunjukkan bahwa faktor kepribadian berperan hingga $71 \%$ dari keseluruhan faktor internal yang mempengaruhi proses pengambilan keputusan karier.

Beberapa pendekatan dilakukan oleh para ahli untuk memahami kepribadian. Costa \& McCrae (1992) mengemukakan teori trait yang menggambarkan model untuk mengidentifikasi trait-trait dasar dalam penggambaran suatu kepribadian. Teori ini kemudian lebih dikenal dengan Big Five Theory of Personality. Big Five teori memiliki keunggulan yaitu dapat digunakan secara universal, sehingga relatif dapat diaplikasikan pada individu dengan budaya yang berbeda (McCrae \& Costa. 2008) serta dapat digunakan dari usia anakanak hingga dewasa (Thompson, 2003). Oleh karena itu, penelitian ini juga menggunakan big five theory personality yang diperkirakan dapat digunakan untuk menjelaskan gambaran kepribadian pada sampel siswa SMA kelas XII.

Big five theory personality terdiri dari lima tipe trait kepribadian yang memiliki 
karakteristik yang berbeda-beda. Kelima trait tersebut adalah openness to experience, conscientiousness, extraversion, agreeableness, neuroticism (Callanan G. A., 2006), atau lebih populer dengan singkatan OCEAN. Menurut Goldberg dalam Ramdhani (2012), seseorang dengan trait openness to experience tinggi digambarkan sebagai seseorang yang senang dengan berbagai informasi baru, suka belajar sesuatu yang baru, dan pandai menciptakan aktivitas yang baru. Sementara, conscientiousness merupakan karakteristik kepribadian yang cenderung sungguh-sungguh dalam melakukan tugas, bertanggung jawab, dapat diandalkan dan menyukai keteraturan dan kedisiplinan. Ciri individu dengan trait extraversion tinggi ditandai dengan adanya semangat dan keantusiasan individu dalam membangun hubungan dengan orang lain dan senang mencari teman baru. Agreeableness yang tinggi ditunjukkan oleh seorang yang mampu menghargai orang lain dibandingkan diri mereka sendiri dan percaya terhadap orang lain. Terakhir, neuroticism tinggi menggambarkan seseorang yang didominasi oleh sifat pencemas mudah gugup dalam menghadapi masalah-masalah, mudah marah ketika berada pada situasi yang tidak sesuai dengan harapannya.

Goldberg (dalam Ramdhani, 2012) mengungkapkan ketika seseorang memiliki ciri kepribadian openness to experience, maka ia selalu mencari pengalamanpengalaman baru, berpikir kreatif, cerdas terhadap masa depan yang akan diraihnya. Oleh karena itu, siswa SMA yang memiliki ciri karakteristik ini akan mencari informasi terlebih dahulu mengenai jurusan atau program studi yang akan dipilihnya. Ia juga mampu mencari informasi mengenai beberapa alternatif ketika tidak mendapatkan jurusan yang akan dijadikan pilihan utama, sehingga cenderung lebih mudah untuk mendapatkan solusi ketika memilih karier yang akan dipilih. Oleh karena itu, pribadi dengan trait openness to experience yang tinggi cenderung memiliki kebimbangan karier yang rendah.

Sejalan dengan hal ini, siswa dengan trait conscientiousness tinggi juga akan lebih mungkin tidak bimbang dalam menentukan kariernya. Costa \& McCrae (1992) mengemukakan bagaimana seseorang dengan nilai conscientiousness tinggi adalah mereka yang memiliki fokus yang baik dalam meraih tujuannya. Secara sistematis, ia akan mampu menentukan langkah-langkah apa saja yang dapat dilakukan untuk menentukan kariernya. Oleh karena itu, siswa SMA kelas XII yang memiliki ciri karakteristik conscientiousness ketika memilih program studi dapat fokus pada jurusan yang menjadi tujuannya, mampu mempersiapkan secara disiplin mengenai jurusan yang akan dipilih. Ia pun dapat menakar kemampuan dirinya sehingga menjadi lebih yakin dengan keputusan yang diambil (Pecjak \& Kosir, 2007).

Berbeda dengan kedua trait sebelumnya, individu dengan tipe kepribadian extraversion yang menonjol adalah seseorang yang cenderung dominan di dalam lingkungan, memiliki antusisasme yang tinggi, tertarik dengan banyak hal (Costa \& McCrae, 1992). Siswa dengan extraversion tinggi akan tertarik dengan banyak hal, termasuk tertarik dengan banyak jurusan dan pilihan karier, sehingga kurang dapat fokus pada satu karier tertentu. Ia juga akan cenderung mengalami konflik dalam menentukan kariernya karena minatnya yang banyak terhadap jurusan yang ada. Dengan demikian, seseorang dengan nilai extraversion tinggi akan cenderung mengalami kebimbangan karier.

Agreeableness tinggi menandakan seseorang dengan ciri karakteristik ramah, mudah percaya dengan orang lain (Goldberg, dalam Ramdhani, 2012). Siswa dengan karakteristik agreeableness tinggi lebih rentan percaya terhadap informasi dan menerima masukan dari orang lain seperti teman, orangtua, guru mengenai pilihan jurusan yang akan dipilihnya. Hal ini membuat seseorang dengan nilai 
agreeableness tinggi cenderung mengalami kebimbangan dalam kariernya karena mempertimbangkan banyak masukan dari luar.

Trait terakhir adalah neuroticism. Seseorang dengan trait neuroticism tinggi akan adalah mereka mudah merasa cemas, tegang, cenderung gugup, takut dan khawatir (Costa \& McCrae, 1992). Maka ketika siswa SMA mengalami kecemasan akan cenderung meningkatkan dimensi personal conflict sehingga ketika ingin memilih jurusan siswa merasa kurang yakin, merasa takut, kurang mampu menentukan ketika dihadapkan beberapah pilihan program studi. Sehingga peneliti memiliki hipotesa terdapat hubungan positif neuroticsm dengan career indecision.

Penelitian mengenai kaitan antara tipe kepribadian big five personality dengan career indecision sudah pernah dilakukan di negara Amerika oleh Lounsbury, Hutchens, \& Loveland (2005). Penelitian tersebut mengungkapkan jika kebimbangan karier berkorelasi negatif dengan tipe kepribadian agreebleness dan conscientiousness, namun berkorelasi positif dengan tipe kepribadian neuroticism, dan sisa trait lainnya tidak berkaitan. Sementara hasil berbeda ditemukan oleh Pečjak \& Košir (2007) pada siswa di Slovenia. Trait conscientiousness dan extraversion yang memiliki korelasi negatif dengan kebimbangan karier. Sementara neuroticism tinggi juga diketahui membuat seseorang lebih sulit dalam membuat (Pečjak \& Košir, 2007).

Penelitian-penelitian tersebut mengungkapkan jika hubungan antara kepribadian dengan kebimbangan karier masih berbeda antara satu dengan lainnya yang mengindikasikan belum ada hasil yang ajek mengenai hubungan kepribadian dengan kebimbangan karier. Hasil penelitian sebelumnya yang telah dilakukan oleh Lounsbury, Hutchens, \& Loveland (2005), di negara Amerika belum dapat sepenuhnya digeneralisasikan pada populasi di Indonesia. Sehingga, peneliti tertarik untuk melihat jika di budaya Indonesia dan penelitian ini menjadi penting untuk dilakukan kembali di Indonesia.

\section{METODE PENELITIAN}

\section{Partisipan}

Partisipan dalam penelitian ini berjumlah 128 orang siswa siswa-siswi SMA kelas XII di JABODETABEK berusia 17-19 tahun, dengan rata-rata usia 18 tahun. Partisipan diminta untuk mengisi kuesioner yang berisi pertanyaan mengenai data diri dan aitem-aitem tiap variabel yang ingin diukur. Mayoritas partisipan (65.6\%) adalah perempuan dan sebagian besar berasal dari SMA Negeri (70,3\%). Separuh dari partisipan $(50 \%)$ adalah peringkat 10 besar di kelasnya. Mayoritas (79,7\%) mengungkapkan jika orang tua merupakan pihak yang paling berperan mempengaruhi mereka dalam pengambilan keputusan karier, sisanya mengakui faktor lain. Mayoritas partisipan $(64,8 \%)$ mendapatkan informasi terkait jurusan berasal dari internet. Kemudian, mayoritas pengeluaran partisipan $(41,2 \%)$ dalam sebulan sebesar < Rp.500.000 dan Rp.500.000 Rp.1.500.000.

\section{Alat Ukur}

Penelitian ini menggunakan BFI versi bahasa Indonesia yang diterjemahkan oleh Ramdhani (2012). Alat ukur ini memiliki 5 dimensi yang diwakili oleh 44 aitem, 15 aitem unfavorable sedangkan sisanya favorable. Kelima dimensi memiliki reliabilitas yang cukup baik, yaitu antara openness to experience (0,79), conscientiousness $(0,78)$, extraversion $(0,73)$, agreeableness $(0,76)$, neuroticism $(0,74)$. Sementara untuk kebimbangan karier diukur oleh Career Decision Scale (CDS) yang dikembangkan oleh Osipow, dkk (1976). Alat ukur ini terdiri dari 18 aitem, dimana 2 aitem pertama merupakan skala kepastian untuk validasi skala lainnya, sedangkan 16 aitem berikutnya berisi skala untuk mengukur tingkat kebimbangan individu (Callanan \& Greenhaus, 2006). Aitem-aitem tersebut akan diberikan skor 
berdasarkan skala likert dengan 4 pilihan, mulai dari 1 = sangat tidak menggambarkan diri saya, hingga $4=$ sangat menggambarkan diri saya. Osipow, dkk., (1976) melaporkan koefisien reliabilitas alat ukur CDS dengan menggunakan metode test-retest pada dua sampel mahasiswa yang berbeda yaitu 0,82 dan 0,90 (Esters, 2007).

\section{ANALISIS DAN HASIL}

Uji hipotesa penelitian dilakukan dengan mengkorelasikan antara masingmasing dimensi big five theory personality dengan variabel kebimbangan karier. Untuk menguji korelasi tersebut data yang terdistribusi normal menggunakan korelasi parametrik Pearson product moment, sedangkan untuk dimensi conscientiousness data tidak berdistribusi normal menggunakan korelasi non-parametrik spearman. Berikut merupakan hasil dari analisa korelasi tersebut:

Tabel 1. Uji Korelasi Big Five Theory Personality dan Career Indecision

\begin{tabular}{lc}
\hline & Kebimbangan Karier \\
\hline Openness to experience & -.161 \\
Extraversion & -.068 \\
Agreeableness & -.095 \\
Neuroticism & $.175^{*}$ \\
Conscientiousness & $-.181^{*}$ \\
\hline$* * \mathrm{p}<0,01 ; * \mathrm{p}<0,05$ &
\end{tabular}

Ditemukan bahwa neuroticsm memiliki hubungan positif dengan kebimbangan karier dengan nilai $(r)=0,175$ $(\rho=0,048<0,05)$ dan conscientiousness memiliki hubungan negatif dengan kebimbangan karier dengan nilai $(\mathrm{r})=$ 0,181 dan $(\rho=0,041<0,05)$. Hal ini menunjukkan bahwa semakin tinggi individu memiliki ciri kepribadian conscientiousness maka akan memiliki kebimbangan karier yang rendah, sementara jika individu memiliki ciri kepribadian neuroticsm mereka akan memiliki tingkat kebimbangan karier yang tinggi ketika menentukan jurusan kuliah. Sedangkan pada dimensi lainnya tidak terdapat hubungan yang signifikan pada dimensi opennes to experience dengan koefisien korelasi $(r)=-0,161 \quad(\rho=0,069>0,05)$, extraversion $(r)=-0,068(\rho=0,446>0,05)$, agreableness $(r)=-0,095(\rho=0,287>0,05)$.

\section{DISKUSI}

Berdasarkan data di atas, ditemukan bahwa terdapat hubungan signifikan negatif antara dimensi conscientiousness dengan kebimbangan karier dengan nilai koefisien korelasi sebesar $(r)=-0,181 \quad(\rho=<0,05)$. Dapat disimpulkan jika semakin tinggi nilai trait conscientiousness pada siswa SMA kelas XII, maka mereka cenderung tidak mengalami kebimbangan karier. Semakin rendah ciri kepribadian conscientiousness pada siswa SMA kelas XII, maka mereka akan lebih mudah bimbang dalam menentukan kariernya. Hasil penelitian ini sejalan dengan penelitian yang dilakukan oleh Lounsbury, Hutchens, \& Loveland (2005) yang menunjukkan bahwa kebimbangan karier berkorelasi negatif dengan tipe kepribadian conscientiousness. Seorang siswa yang lebih tertata dan terstruktur, akan lebih sistematis dan gigih dalam mengeksplorasi dan memilih jurusan yang ingin dipilihnya. Siswa yang mempunyai skor tinggi pada ciri kepribadian conscientiousness cenderung mengejar tujuan dalam satu cara yang terarah, bertanggung jawab, dan berorientasi pada prestasi. Oleh karena itu, orang yang memiliki ciri kepribadian conscientiousness akan akan fokus pada jurusan yang menjadi tujuannya, mampu mempersiapkan secara disiplin mengenai jurusan yang akan dipilih dan akan lebih yakin dengan keputusan yang diambil, sehingga kecil kemungkinan mereka mengalami kebimbangan ketika menentukan jurusan.

Ditemukan pula hubungan signifikan positif antara neuroticsm dengan kebimbangan karier dengan nilai koefisien korelasi sebesar $(r)=0,175 \quad(\rho=$ $0,048>0,05)$. Hasil ini mengindikasikan, ciri kepribadian neuroticsm yang tinggi pada siswa SMA kelas XII akan membuat 
mereka memiliki kebimbangan karier yang tinggi pula. Hal ini sejalan dengan penelitian yang dilakukan pada penelitian Kelly \& Pulver (dalam Al-Kalbani, Salleh, \& Mastor, 2011) menemukan bahwa seseorang yang memiliki ciri kepribadian neuroticsm dalam mengambil keputusan disertai dengan ragu-ragu dan takut gagal. Karena pemilihan karier merupakan salah satu keputusan yang akan menjadi pengaruh besar dalam kehidupan manusia. Oleh karena itu, siswa SMA kelas XII dengan tipe kepribadian tersebut akan mengalami kebimbangan pada saat proses pengambilan keputusan karier. Siswa SMA kelas XII dengan ciri-ciri kepribadian neuroticism ketika memilih jurusan cenderung kurang yakin, merasa khawatir, cemas, kurang mampu dalam menentukan beberapa pilihan program studi yang akan dipilihnya.

Dimensi agreeableness tidak memiliki hubungan yang signifikan dengan kebimbangan karier dengan nilai koefisien korelasi sebesar $(r)=-0,095 \quad(\rho=$ $0,287>0,05)$. Hasil penelitian ini memiliki perbedaan dengan penelitian yang dilakukan oleh Lounsbury, Hutchens, \& Loveland (2005) yang menunjukkan bahwa kebimbangan karier berkorelasi negatif dengan tipe kepribadian agreeableness. Siswa SMA kelas XII yang memiliki sifat agreeableness menerima lebih banyak perhatian dan dukungan dari guru, konselor dalam perencanaan dan pengembangan karier. Siswa SMA kelas XII yang memiliki sifat agreeableness juga lebih rentan untuk percaya informasi orang lain tentang pilihan karier dan mendengar masukan dari orang lain mengenai pilihan jurusan yang akan dipilihnya (Lounsbury, Hutchens, \& Loveland, 2005)

Hubungan antara openness to experience dimensi dari big five theory of personality tidak memiliki hubungan signifikan dengan kebimbangan karier dengan nilai koefisien korelasi sebesar $(r)=$ $-0,161(\rho=0,069>0,05)$. Siswa SMA kelas XII yang memiliki ciri kepribadian openness to experience selalu mencari pengalaman-pengalaman baru dan berpikir kreatif mengenai masa depan yang akan diraihnya, sehingga siswa SMA yang memiliki ciri karakteristik ini ketika memilih jurusan. Menurut Pečjak \& Košir (2007), seorang siswa yang berpikir kreatif mengenai masa depan dapat menemukan jurusan yang optimal baginya, dan akan lebih cepat menentukan jurusan dalam proses pengambilan keputusan dibandingkan siswa yang tidak memiliki ciri karakteristik openness to experience. Oleh karena itu, siswa SMA kelas XII yang memiliki ciri kepribadian ini cenderung tidak mudah untuk mengalami kebimbangan karier. Karena ciri kepribadian ini mampu mencari informasi baru terkait pilihan jurusan atau program studi yang akan dipilihnya. Selain itu, siswa sma kelas XII memiliki beberapa alternatif jurusan, sehingga cenderung lebih mudah untuk mendapatkan solusi ketika memilih karier yang akan dipilih.

Selain itu, extraversion tidak memiliki hubungan signifikan dengan kebimbangan karier dengan nilai koefisien korelasi sebesar $(r)=-0,068 \quad(\rho=$ $0,446>0,05)$. Seseorang yang memiliki kepribadian extraversion cenderung dominan di dalam lingkungan, memiliki antusisasme yang tinggi, tertarik dengan banyak hal. Sehingga siswa SMA kelas XII yang memiliki ciri karakteristik ini ketika memilih jurusan akan cenderung mengalami kebimbangan dalam mengambil keputusan kariernya, karena individu dengan tipe kepribadian extraversion tertarik dengan banyak hal yang akan menyebabkan cepat dan mudah merubah pilihan program studi yang akan dipilihnya.

Hasil lain dari penelitian ini juga menunjukkan tidak terdapat perbedaan signifikan antara kebimbangan karier yang dimiliki siswa-siswi SMA kelas XII dengan dua variabel demografi yaitu orang yang paling berpengaruh dalam pengambilan keputusan dan sumber informasi yang didapatkan dalam pengambilan keputusan. Hal tersebut tidak sejalan dengan penelitian yang dilakukan oleh Mau (2000) seseorang yang berpengaruh dalam pengambilan 
keputusan karier adalah pihak otoritas, seperti orangtua dan guru, sehingga ketika akan mengambil keputusan seseorang akan meminta persetujuan kepada pihak otoritas. Karena siswa SMA kelas XII saat ini dalam mengambil keputusan, lebih mampu mencari informasi terkait jurusan yang diinginkan. Tidak dapat dipungkiri bahwa internet merupakan bagian dari hidup saat ini, bahkan termasuk bagian terpenting dalam pendidikan yang antara lain digunakan untuk mencari informasi penting yang berkaitan dengan pendidikan. Hal tersebut yang menyebabkan pihak otoritas tidak lagi berperan di dalam pengambilan keputusan.

\section{SIMPULAN}

Hasil dari penelitian ini menunjukkan bahwa terdapat hubungan positif pada dimensi neuroticsm dengan kebimbangan karier pada siswa SMA Kelas XII. Kemudian terdapat hubungan negatif pada dimensi conscientiousness dengan kebimbangan karier. Sedangkan pada dimensi lainnya tidak terdapat hubungan yang signifikan.

\section{SARAN}

Berdasarkan hasil penelitian ini, upaya yang dapat dilakukan untuk menurunkan kebimbangan karier siswa adalah dengan mengurangi ciri kepribadian neuroticism dan mengembangkan ciri kepribadian conscienstiousness pada remaja. Berikut ini adalah beberapa saran praktis yang dapat diberikan:

- Bagi siswa yang akan memilih jurusan di universitas disarankan untuk mengurangi perasaan cemas, takut, dan mudah gugup dalam menentukan jurusan. Upaya yang dapat dilakukan adalah dengan mencari informasi kepada kerabat dan rekan yang sudah lebih dahulu memilih jurusan yang sesuai dengan yang diinginkan, berdiskusi dengan orang tua dan berdoa untuk meminta petunjuk agar membuat keputusan yang tepat.

- Untuk siswa SMA kelas XII disarankan lebih mengenali diri, misalnya mulai dari hobi, melihat nilai atau prestasi belajar pada mata pelajaran apa yang paling mudah dipahami dimulai dari kelas XI. Hal ini dapat membantu siswa dalam membuat perencanaan yang terstruktur.

- Untuk pihak Sekolah Menengah Atas (SMA) disarankan untuk lebih memberikan banyak informasi terkait berbagai alternatif jurusan agar dapat mengurangi kecemasan dan meeningkatkan perencanaan pada siswa. Hal ini dapat dicapai dengan mengadakan pameran pendidikan atau career day yang memberikan informasi pilihan jurusan dan langkah-langkah dalam memilih jurusan.

\section{DAFTAR PUSTAKA}

Bardick, A.D., Bernes, K.B., Magnusson, K.C., \& Witco, K.D. 2006. Junior high school students' career plans for the future: A Canadian perspective. Journal of Career Development, 32, 250-271.

Callanan, G. A., \& Greenhaus, J. H. (2006). Encyclopedia of Career Development Vol. 01. Sage Publications.

Costa, P. T., \& McCrae, R. R. (1992). Revised NEO personality inventory (NEO PI-R) and NEP five-factor inventory (NEOFFI): professional manual. Lutz, FL: Psychological Assessment Resources.

Daniels, L. M., Stewart, T. L., Stupnisky, R. H., Perry, R. P., \& LoVerso, T. (2011). Relieving career anxiety and indecision: the role of undergraduate students' perceived control and faculty affiliations. Social Psychology of Education, 14(3), 409-426. doi: 10.1007/s11218-010-9151$\mathrm{X}$

Gati, I., \& Saka, N. (2001). High School Students' Career-Related DecisionMaking Difficulties. Journal of Counseling \& Development, 79(3), 331$340 . \quad$ Doi: $10.1002 / J .1556-$ 6676.2001.Tb01978.X 
Guay, F. (2006). Distinguishing Developmental From Chronic Career Indecision: SelfEfficacy, Autonomy, and Social Support. Journal of Career Assessment, 14(2), 235-251.

Doi: $10.1177 / 1069072705283975$

Gunawan, Yusuf. (2001). Pengantar Bimbingan dan Konseling Buku Panduan Mahasiswa. Jakarta: Prenhallindo.

Jamali, Y., Araqi, V., \& Kalantarkousheh, S.M. (2015). Function of Dysfunctional Career Thoughts, Procrastination and Career Indecision among Allameh Tabatab'i University Students. Journal of Natural and Social Sciences, 4(1), 57-65.

Lounsbury, J. W., Hutchens, T., \& Loveland, J. M. (2005). An Investigation of Big Five Personality Traits and Career Decidedness among Early and Middle Adolescents. Journal of Career Assesment, 13(1), 29-39.

Mau, W.-C. (2000). Cultural Differences in Career Decision-Making Styles and SelfEfficacy. Journal of Vocational Behavior, 57(3), 365-378.

McCrae, R. R., \& Costa, P. T., Jr. (2008). Empirical and theoretical status of the five-factor model of personality traits.
Sage Handbook of personality theory and assessment. Vol. 1. Los Angeles, CA: Sage.

Papalia, D. E., Olds, S. W., \& Feldman, R. D. (2009). Human Development (11th ed). New York: McGraw-Hill

Pramudi, H. (2015). Kemampuan pengambilan keputusan karir siswa kelas XI di SMA Negeri 1 Kutasari Purbalingga. Jurnal Riset Mahasiswa Bimbingan dan Konseling, 4(4).

Ramdhani, N. (2012). Adaptasi Bahasa dan Budaya dari Skala Kepribadian Big Five. Jurnal Psikologi, 39(2), 189-205.

Sasongko, A. U. B. (2015). Survei Pemilihan Karir Mahasiswa Fakultas Ekonomi Universitas Negeri Surabaya. Jurnal BK UNESA, 5(2).

Setyowati, D. D., \& Nursalim, M. (2015). Pengaruh Layanan Informasi Studi Lanjut Terhadap Kemantapan Pengambilan Keputusan Studi Lanjut. Fakultas Ilmu Pendidikan, Universitas Negeri Surabaya.

Wandansari, Y. (2004). Persepsi Terhadap Dukungan Orang Tua dan Pembuatan Keputusan Karier Pada Remaja. Jurnal Provitae, 1(1), 59-81. 